\title{
Gynecomastia: An Uncommon but Important Clinical Manifestation for Testicular Tumors
}

\author{
Zhanyong Bing*, Shuting Bai \\ Department of Pathology and Laboratory Medicine, Hospital of the University of Pennsylvania, Philadelphia, USA. \\ Email: *bingz@uphs.upenn.edu
}

Received December $6^{\text {th }}, 2011$; revised January $22^{\text {nd }}, 2011$; accepted January $30^{\text {th }}, 2011$

\begin{abstract}
Abstract: Gynecomastia is a benign enlargement of male breast tissue due to the proliferation of the ductal component. It can be physiological or pathological. Gynecomastia can be a sign for testicular tumors including sex-cord stromal tumors and germ cell tumors. Testicular physical examination in combination with testicular untrasonography and serum germ cell tumor markers when necessary in the presence of gynecomastia can help to reach a correct diagnosis.
\end{abstract}

Keywords: Gynecomastia; Testicular Tumors

\section{Gynecomastia}

Gynecomastia is benign enlargement of male breast tissue due to the proliferation of the ductal component $[1,2]$. It can be unilateral or bilateral. Its incidence has a trimodal distribution with $60 \%-90 \%$ in neonates, $50 \%-60 \%$ in adolescents, and up to $70 \%$ in men aged $50-69$ years [3]. It can be physiological or pathological. The pathogenesis of gynecomastia is due to the loss of equilibrium between estrogen and androgen caused by a feminizing state. Feminizing states can be roughly classified into three categories. First is the absolute increase of estrogen, such as direct secretion by tumors, increased estrogen precursor in cirrhosis, or rare incidences of genetic disease with extraglandular synthesis of estrogen. Second is the relative imbalance of estrogen and androgen, such as with medications, including estrogen itself; drugs that mimic estrogen, such as digitalis; or drugs that inhibit the action of androgen, such as cimentidine or spironolactone. Finally, luteinizing hormone or human chorionic gonadotropin (hCG) may directly act on male breast tissue [4,5]. Gynecomastia can be a sign for testicular tumors including sex-cord stromal tumors and germ cell tumors. Testicular physical examination, in combination with testicular untrasonography, and serum germ cell tumor markers when necessary in the presence of gynecomastia, can be used to exclude such a possibility. In this review, we will discuss testicular tumors in relation to gynecomastia.

\section{Testicular Tumors}

Testicular tumors are relatively rare, with approximately

"Corresponding author.
$95 \%$ with germ cell origin, while the rest are accounted for by sex-cord stromal tumors and other miscellaneous tumors [6].

\subsection{Sex-Cord Stromal Cell Tumors and Gynecomastia}

\subsubsection{Leydig Cell Tumors}

Leydig cells are interstitial cells located between the seminiferous tubules, which secrete testosterone when stimulated by luteinizing hormone. Leydig cell tumors (LCTs) account for $0.8 \%-3 \%$ of all testicular neoplasm [7-9]. Testicular LCTs can occur at any age but commonly occur in prepubertal boys (most often between 5 - 10 years old) and in adults between 30 - 60 years of age. Approximately $15 \%$ - $30 \%$ of Leydig cell tumors present with gynaecomastia [10-12].

The tumors are benign in children but approximately $10 \%$ that occurs in adults are malignant [7]. Macroscopically, LCTs are typically well circumscribed and uniformly solid, and show characteristic gold brown cut surface. Occasionally the tumor may be gray, white brown or green brown on cut surfaces. Necrosis or hemorrhage may be present and these two features raise the concern for malignancy. Microscopically the tumors grow as diffuse proliferations or may grow in nests or sheets separated by delicate fibrovascular septa. Occasionally, the tumor may grow in insular, trabecular, pseudotubular, or ribbonlike patterns. Necrosis may give the tumor a pseudopapillary appearance. The tumor cells have abundant eosinophilic, finely granular cytoplasm and regular round nuclei which are located either centrally or eccentrically (Figure 1(A)). 

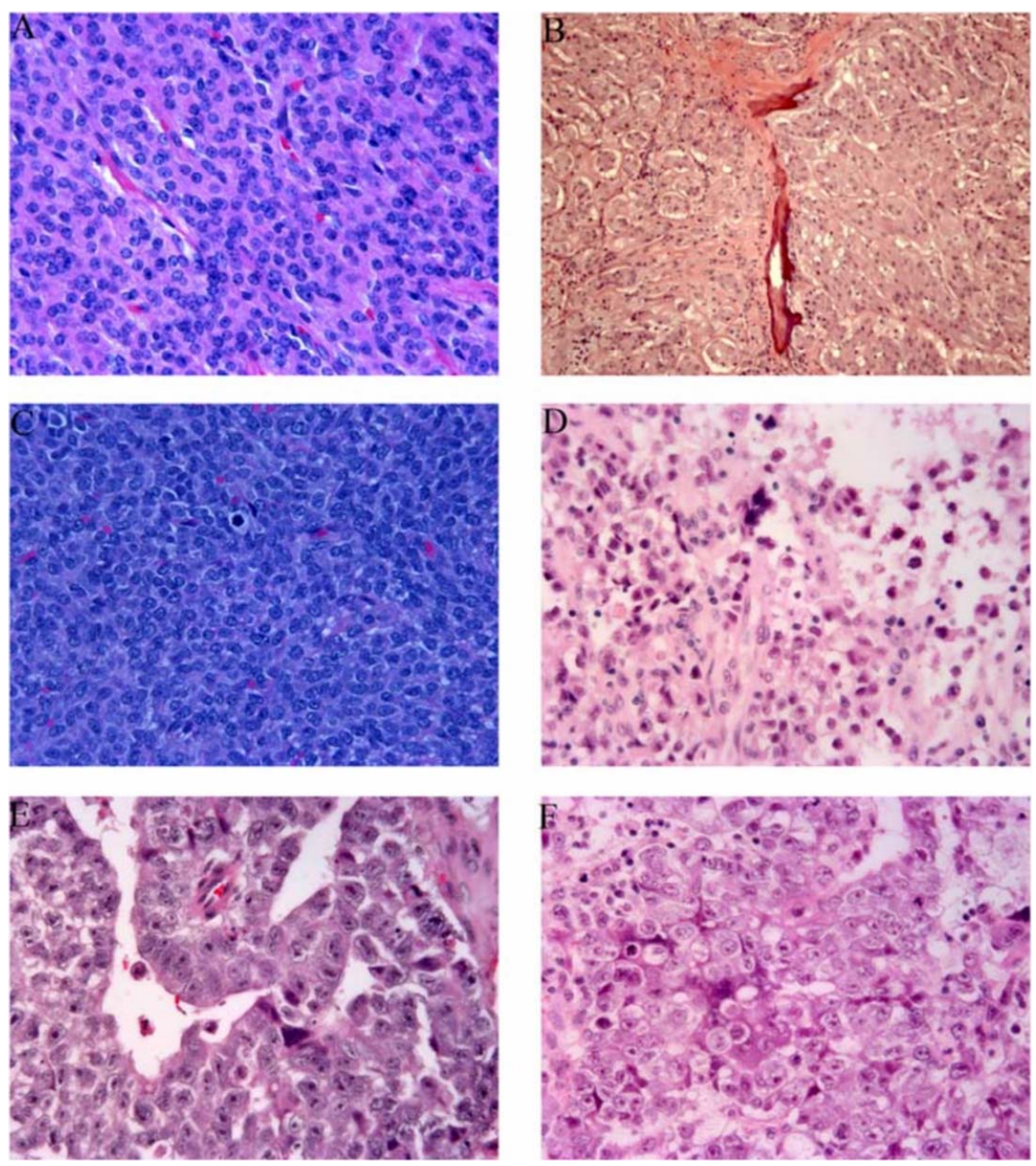

Figure 1. Testicular tumors. (A) Leydig cell tumor, H \& E, ×400; (B) Large cell calcifying Sertoli cell tumor, H \& E, ×400; (C) Adult type granulosa cell tumor, H \& E, ×400; (D) Classic seminoma with syncyciotrophoblasts, H \& E, ×400; (E) Embryonal carcinoma, H \& E, ×400; (F) Choriocarcinoma, H \& E, ×400.

Some tumor cells may have single or multiple small nucleoli. The cytoplasm contains abundant lipofuscin, which appears golden yellow to brown on hematoxylin and eosin stained slides. Reinke crystals may be present in fewer than half of the LCTs; these are pale staining, refractive, cylindrical, rectangular or rhomboid structures. The Reinke crystals can be present in either the cytoplasm or the nucleus.

Some unusual morphologic features of this tumor has been described $[13,14]$. It has been shown that Leydig cell tumor can be cystic [14], thereby mimicking yolk sac tumor or having adipose differentiation, spindle cell feature, or with calcification or ossification. Such rare morphology does not seem to carry a prognostic significance [15], although awareness of variable morphology will help to make the correct diagnosis. In difficult cases, immunohistochmical stain for inhibin may be useful.

The behavior of LCTs depends on tumor size, mitosis, and infiltrative growth. If the tumor is greater than $5 \mathrm{~cm}$ in size, with necrosis, lymphovascular invasion, marked cytological atypia and increased mitosis ( $>3-5 / 10$ high power fields), the tumor likely will behave aggressively [7].

LCTs are commonly associated with excess of steroid hormones. They can produce androgens, mainly testosterone, but can also produce estrogen [16-19] (by either directly secretion of estradiol or by peripheral testosterone aromatization). Pediatric patients with androgen secreting tumors usually present with precocious puberty; in adults, this secretion rarely causes any notable effects. Estrogensecreting tumors can lead to feminizing stigmata includeing gynecomastia in both adolescents and adults.

\subsubsection{Sertoli Cell Tumors}

Sertoli cells provide nutrition for the germ cells during spermatogenesis, form the blood and testis barrier and may also play a role in immunoregulation [20].

The classification of Sertoli cell tumors is divided into four categories: 1) Sertoli cell tumor, not otherwise specified occurring in both ovary and testicle, and account- 
ing for most cases of the tumors; 2) lipid rich variant, almost always occurring in the ovary; 3 ) large cell calcifying variant, exclusively occurring in testis; and 4) sclerosing variant, almost always found in the testis [21].

\subsubsection{Sertoli Cell Tumor, Not Otherwise Specified}

These tumors account for $<1 \%$ of testicular tumors and may occur in any age but with a peak incidence at $35-50$ years of age. The percentage of Sertoli cell tumors presenting with gynecomastia is difficult to determine from the current literature [21].

The tumors are almost always unilateral. On cut surface, the tumors are typically well circumscribed, sometime lobulated, and are tan, gray or white in color. Cystic changes may be present. Necrosis or hemorrhage may be seen and these raise concern for malignant behavior. Microscopically the tumors commonly have tubular formation. The tumor is typically composed of polygonal cells with moderate to abundant pale cytoplasm. Half of the tumor may contain cytoplasmic vacuoles due to intracytoplasmic lipid.

Some tumors may have diffuse growth with only limited tubular formation [22], which is particularly likely seen in malignant tumors because of the poor differentiation in such cases [23]. The diffuse growth in combination with other features such as clear cytoplasm, prominent nucleoli, and lymphoid infiltrate may lead to the confusion with seminoma, mostly of classic type but occasionally of spermatocytic type. Tubular formation is critical for the correct diagnosis. Ample sampling is therefore important. In difficult cases, immunohistochemical stains for placentalike alkaline phosphatase, or newly described markers for classic seminoma such as OCT4 [24], SALL4 [25] and NANOG [26] may be helpful. In addition no intratubular germ cell neoplasia is present in the adjacent testicular tissue of Seroti cell tumors. Other issues in differential diagnosis are limited and may include yolk sac tumors when the tumors show prominent cystic changes, rete cystoadenoma, or even adenomatoid tumor when the cytoplasm of the tumor cells shows vacuoles. Sertoli cell tumor does not have the typical cytology for yolk sac tumor. Rete cystoadenoma may have a Sertoliform pattern [27], but have discrete rete location. For adenomatoid tumor, characteristic immunohistochemical stains may help to resolve the issue.

The tumor behavior depends on conventionally worrisome features including large tumor size $(>5 \mathrm{~cm})$, necrosis, vascular invasion, moderate to severe nuclear atypia and higher mitotic rate ( $>5 / 10 \mathrm{HPF}$ ) [22]. Tumors with a seminoma-like appearance have a high tendency to metastasize even when the primary tumor measures less than $5 \mathrm{~cm}[21]$.

\subsubsection{Large Cell Calcifying Sertoli Cell Tumor (LCCSCT)}

LCCSCT occurs exclusively in the testis and average age at presentation is 21 years. Approximately $20 \%$ of this variant are bilateral, which are almost exclusively associated with Carney's syndrome [21] (a multiple endocrine neoplasia syndrome manifested as spotty skin pigmentation, myxomas of heart or other sites, endocrine neoplasms, and psammomatous melanotic schwannomas [28]). Approximately $10 \%$ of LCCSCT are associated with gynecomastia [29].

Grossly there may be gritty sensation upon sectioning due to the calcification. Microscopically it composed of nodules of large, round, cuboidal or columnar Sertoli cells with abundant eosinophilic, often vacuolated cytoplasm growing in sheets, nests, cords, ribbons and trabeculae. Foci of calcification are characteristic and are considered one of diagnostic criteria [30] (Figure 1(B)). LCCSCT is usually benign [29,31]. Malignant tumors are unilateral, and solitary; they occur in an older age group (mean age, 39 years), whereas the benign ones are bilateral and multifocal in more than a quarter of cases and occur in younger individuals (average age 17 years) [29]. The morphological features associated with aggressive behaviors include large size $(>4 \mathrm{~cm})$, necrosis, vascular invasion, high mitotic rate ( $>3 / \mathrm{HPF})$ and extratesticular extension [29].

\subsubsection{Intratubular Large Cell Hyalinizing Sertoli Cell Neoplasia and Peutz-Jeghers Syndrome}

Patients with Peutz-Jeghers syndrome and testicular Sertoli cell tumors commonly presents with gynecomastia $[21,32]$. The testicular Sertoli cell tumors have unique histology. Ulbright et al [32] reported 8 such cases and the patients ranged from 4 - 13 years of age (mean, 6.5 years) and all had gynecomastia, moreover, in 7 out of 8 cases, it was the presenting symptom. The boys showed enlarged testicles without discrete masses. Three patients also showed advanced bone age and four had elevated estradiol. Testicular biopsy was performed on all patients. Histologically patches of seminiferous tubules were infiltrated and expanded by large Sertoli cells with vacuolated to eosinophilic cytoplasm. Basement membrane globules were seen to admix with such Sertoli cells and were extended from thickened peritubular basement membranes. Small calcifications were seen in three out of eight cases. No tumor invasion was identified in any cases. The prognosis of this type of tumor is usually indolent. Therefore, the authors recommended follow-up including ultrasonography instead of orchiectomy [32].

The pathogenesis of gynecomastia in Sertoli cell tumors is due to the increased ratio of estrogen to androgen by increasing the aromatization of estrogen precursors by the tumor cells $[17,33]$.

\subsubsection{Granulosa Cell Tumors}

Granulosa cell tumor is extremely rare in the adult testicles and it can be classified into juvenile and adult types. 
Juvenile granulosa cell tumor usually occurs in the pediatric group and very rarely in adult [34]. It represents the most common neoplasm in the testicles in the first 6 months of life and is clinically benign [35-37]. Histologically the tumor is multicystic. The cysts are lined by several layers of cells with the inner layer siminar to granulosa cells; and outer layer similar to theca cells. Granulosa-like cells are round with spherical, smooth-contoured, non-hyperchromatic nuclei with inconspicuous nucleoli. Theca-like cells are elongated with scant cytoplasm.

Testicular granulosa cell tumor in adults are mostly adult type [38,39]. Only 29 cases of adult type testicular granulosa cell tumor have been reported [38-47]. The average age at presentation is 45 years (range $16-77$ years).

Testicular granulosa cell tumors usually present as a painless mass in the testicle. Five of 29 reported cases show gynecomastia at presentation (17\%) [48-51] The adult testicular granulosa cell tumors usually do not invade tunica albuginea, but focal infiltration of testicular parenchyma can be present [39]. No lymphovascular invasion is seen. The tumor can grow in multiple patterns, including trabecular, insular, macrofollicular, microfollicular and gyriform patterns. The nuclei are elongated, sometimes with nuclear grooves. No prominent nucleoli are seen. Mitotic rate is highly variable, ranging from 2 per 50 HPF to 3 per HPF $[43,52]$. Call-Exner bodies may be seen.

The differential diagnosis for the granulosa cell tumors includes germ cell tumors especially yolk sac tumor, metastatic carcinoma, carcinoid tumors or malignant lymphoma.

Granulosa cell tumors can synthesize estrodiol [53] and therefore disrupt the equilibrium of estrogen and androgen and lead to gynecomastia.

\subsection{Germ Cell Tumors and Gynecomastia}

Type II germ cell tumors are the most common cancers in men in their third or fourth decades of life [54], accounting for $1 \%-1.5 \%$ of all tumors in male population $[54,55]$ and $5 \%$ of urological neoplasms [55] with an incidence of 3 - 6 cases per 100,000 men per year $[54,55]$ in western countries.

Germ cell tumor may not have a palpable mass and may present first with gynecomastia $[6,56,57]$. Two to four percent of gynecomastia may be the initial presentation of testicular tumors $[17,58]$, while $5 \%-7 \%$ of patients with testicular germ cell tumors will have gynecomastia at the initial presentation with equal incidence between classic seminoma and non-seminoma [59]. Ten percent of hCG secreting testicular tumors have initial presentation of gynaecomastia [60]. Patients with testicular tumors and gynecomastia may have a worse prognosis than men without this symptom $[61,62]$.

Germ cell tumors (GCTs) have been proposed to arise from a common precursor lesion called intratubular germ cell neoplasia unclassified [63-65]. The invasive lesions can be divided into seminoma and non-seminomaous tumors including embryonal carcinoma, yolk sac tumor, teratoma, choriocarcinoma, and mixed forms [66].

Classic seminoma accounts for $40 \%$ of GCTs and commonly occurs in fourth decade of life. It is composed of cells with clear cell border, abundant cytoplasm and hyperchromatic nuclei with prominent nucleoli. The tumor commonly has the characteristic fibrous septae with infiltrated lymphocytes. Approximately $7 \%$ classic seminomas have scattered syncytiotrophoblasts (Figure 1(D)), which may account for the low level of increase of hCG level in some patients with seminoma $[67,68]$, and the presence of gynecomastia $[69,70]$.

Nonseminomatous GCTs account for approximately $60 \%$ of all GCTs and occur about one decade earlier than the classic seminoma. Embryonal carcinoma is a component in about $40 \%$ of GCTs. Pure embryonal carcinoma is rare. It can grow in solid, glandular or papillary patterns without distinct cell borders. The nuclei overlap with each other with prominent nucleoli. Necrosis and hemorrhage are common. Mitotic rate is brisk. Embryonal carcinoma commonly has lymphovascular invasion. Up to $2 / 3$ of patients have metastasis at initial presentation and staging. Embryonal carcinoma may have slightly elevated hCG [71,72], which may be due to the syncytiotrophoblastic differentiation of the embryonal cells [72] (Figure 1(E)). Choriocarcinoma is associated with drastic elevation of hCG [67]. Pure choriocarcinoma is rare. It is usually seen mixed with other components of germ cell tumor. It disseminats by the hematogenous route, and blood vessel invasion is common. It grows in biphasic pattern composed of syncytiotrophoblasts and cytotrophoblasts (Figure 1(F)). This type of GCT has the poorest prognosis of all tumors in this group.

GCTs show excellent cure rate with $90 \%-95 \%$ of patient with organ confined or low volume retroperitoneal metastatic disease being cured [16]. However delay in diagnosis may lead to high stage in presentation and worse outcome following treatment [16,59].

The pathogenesis of gynecomastia in testicular germ cell tumors is largely due to the increased level of human chorionic gonadotropin. hCG is a glycoprotein with a unique $\beta$-subunit but sharing a common $\alpha$-subunit with luteinizing hormone, thyroid stimulating hormone and follicle-stimulating hormone. $\mathrm{hCG}$ can be elevated in several tumor types with the folds of elevation dependent on the histological types of the tumors. In tumors with choriocarcinoma component, hCG can be dramatically increased. In embryonal carcinoma and seminoma, $\mathrm{hCG}$ can also be elevated, albeit at a much lower range. hCG promotes steroidogenesis [58], leading to both increased secretion of estrogen and testosterone. The level of estrogen increase, however, is higher than testosterone, and, causes an increased ratio of estrogen and testosterone resulting in gynecomastia. 


\section{Conclusions}

Gynecomastia can be a sign for testicular cancers including sex-cord stromal tumors and germ cell tumors. The underlying mechanism is due to the loss of equilibrium between estrogen and androgen caused by a feminizing state, which includes the absolute increase of estrogen or its precursors, increase of the aromatization of estrogen precursors or increased secretion of hCG. Testicular examination is important to evaluate such possibility. Ultrasonography, and measurements of serum AFP and HCG levels should be used to exclude testicular pathology $[73,74]$ when necessary.

Acknowledgement: The author thanks Dr. Deqin Ma for kindly providing a photograph of large cell calcifying Sertoli cell tumor. The author also thanks Dr. Virginia LiVolsi for suggestions and for reviewing the manuscript.

\section{REFERENCES}

[1] G. D. Braunstein, "Diagnosis and Treatment of Gynecomastia," Hospital Practice, Vol. 28, No. 10A, pp. 37-46.

[2] G. D. Braunstein, "Clinical Practice, Gynecomastia," New England Journal of Medicine, Vol. 357, No. 12, 2007, pp. 1229-1237. doi:10.1056/NEJMcp070677

[3] R. E. Johnson, C. A. Kermott and M. H. Murad, "Gynecomastia: Evaluation and Current Treatment Options," Journal of Therapeutics and Clinical Risk Management, Vol. 7, 2011, pp. 145-148.

[4] H. E. Carlson, P. Kane, Z. M. Lei, X. Li and C. V. Rao, "Presence of Luteinizing Hormone/Human Chorionic Gonadotropin Receptors in Male Breast Tissues," Journal of Clinical Endocrinology, Vol. 89, No. 8, 2004, pp. 4119-4123. doi:10.1210/jc.2003-031882

[5] J. D. Wilson, "Gynecomastia: A Continuing Diagnostic Dilemma," New England Journal of Medicine, Vol. 324, No. 5, 1991, pp. 334-335. doi:10.1056/NEJM199101313240510

[6] H. C. Hassan, I. M. Cullen, R. G. Casey and E. Rogers, "Gynaecomastia: An Endocrine Manifestation of Testicular Cancer," Andrologia, Vol. 40, No. 3, 2008, pp. 152157. doi:10.1111/j.1439-0272.2007.00815.x

[7] O. M. Al-Agha and C. A. Axiotis, "An In-Depth Look at Leydig Cell Tumor of the Testis," Archives of Pathology \& Laboratory Medicine, Vol. 131, No. 2, 2007, pp. 311-317.

[8] M. A. Rich and M. A. Keating, "Leydig Cell Tumors and Tumors Associated with Congenital Adrenal Hyperplasia," Urologic Clinics of North America, Vol. 27, No. 3, 2000, pp. 519-528. doi:10.1016/S0094-0143(05)70099-9

[9] N. Suardi, E. Strada, R. Colombo, M. Freschi, A. Salonia, C. Lania, A. Cestari, L. Carmignani, G. Guazzoni, P. Rigatti and F. Montorsi, "Leydig Cell Tumour of the Testis: Presentation, Therapy, Long-Term Follow-Up and the Role of Organ-Sparing Surgery in a Single-Institution Experience," British Journal of Urology International, Vol. 103, No. 2, 2009, pp. 197-200.
doi:10.1111/j.1464-410X.2008.08016.x

[10] L. Carmignani, R. Salvioni, F. Gadda, M. Colecchia, G. Gazzano, T. Torelli, F. Rocco, G. M. Colpi and G. Pizzocaro, "Long-Term Follow-Up and Clinical Characteristics of Testicular Leydig Cell Tumor: Experience with 24 Cases," Journal of Urology, Vol. 176, No. 5, 2006, pp. 2040-2043. doi:10.1016/j.juro.2006.07.005

[11] D. S. Conkey, G. C. Howard, K. M. Grigor, D. B. McLaren and G. R. Kerr, "Testicular Sex Cord-Stromal Tumours: The Edinburgh Experience 1988-2002, and a Review of the Literature," Clinical Oncology, Vol. 17, No. 5, 2005, pp. 322-327. doi:10.1016/j.clon.2005.04.009

[12] I. Kim, R. H. Young and R. E. Scully, "Leydig Cell Tumors of the Testis. A Clinicopathological Analysis of 40 Cases and Review of the Literature," American Journal of Surgical Pathology, Vol. 9, No. 3, 1985, pp. 177-192. doi:10.1097/00000478-198503000-00002

[13] S. D. Billings, L. M. Roth and T. M. Ulbright, "Microcystic Leydig Cell Tumors Mimicking Yolk Sac Tumor: A Report of Four Cases," American Journal of Surgical Pathology, Vol. 23, No. 5, 1999, pp. 546-551. doi:10.1097/00000478-199905000-00008

[14] J. C. Cheville, T. J. Sebo, D. J. Lager, D. G. Bostwick and G. M. Farrow, "Leydig Cell Tumor of the Testis: A Clinicopathologic, DNA Content, and MIB-1 Comparison of Non Metastasizing and Metastasizing Tumors," American Journal of Surgical Pathology, Vol. 22, No. 11, 1998, pp. 1361-1367. doi:10.1097/00000478-199811000-00006

[15] R. H. Young, "Testicular Tumors-Some New and a Few Perennial Problems," Archives of Pathology \& Laboratory Medicine, Vol. 132, No. 4, 2008, pp. 548-564.

[16] G. J. Bosl and R. J. Motzer, "Testicular Germ-Cell Cancer," New England Journal of Medicine, Vol. 337, No. 4, 1997, pp. 242-253. doi:10.1056/NEJM199707243370406

[17] G. D. Braunstein, "Gynecomastia," New England Journal of Medicine, Vol. 328, No. 7, 1993, pp. 490-495. doi:10.1056/NEJM199302183280708

[18] L. Foppiani, D. Bernasconi, P. Del Monte, A. Marugo, C. Toncini and M. Marugo, "Leydig Cell Tumour-Induced Bilateral Gynaecomastia in a Young Man: Endocrine Abnormalities," Andrologia, Vol. 37, 2005, pp. 36-39. doi:10.1111/j.1439-0272.2004.00648.x

[19] S. Zarrilli, G. Lombardi, L. Paesano, C. Di Somma, A. Colao, V. Mirone and M. De Rosa, "Hormonal and Seminal Evaluation of Leydig Cell Tumour Patients before and after Orchiectomy," Andrologia, Vol. 32, No. 3, 2000, pp. 147-154. doi:10.1046/i.1439-0272.2000.00356.x

[20] M. Fijak, S. Bhushan and A. Meinhardt, "Immunoprivileged Sites: The Testis," Methods in Molecular Biology, Vol. 677, 2011, pp. 459-470. doi:10.1007/978-1-60761-869-0 29

[21] R. H. Young, "Sex Cord-Stromal Tumors of the Ovary and Testis: Their Similarities and Differences with Consideration of Selected Problems," Modern Pathology, Vol. 18, Suppl. 2, 2005, pp. S81- S98. doi:10.1038/modpathol.3800311

[22] R. H. Young, D. D. Koelliker and S. E. Scully, "Sertoli 
Cell Tumors of the Testis, not Otherwise Specified: A Clinicopathologic Analysis of 60 Cases," American Journal of Surgery Pathology, Vol. 22, No. 6, 1998, pp. 709-721. doi:10.1097/00000478-199806000-00008

[23] J. D. Henley, R. H. Young and T. M. Ulbright, "Malignant Sertoli Cell Tumors of the Testis: A Study of 13 Examples of a Neoplasm Frequently Misinterpreted as Seminoma," American Journal of Surgery Pathology, Vol. 26, No. 5, 2002, pp. 541-550. doi:10.1097/00000478-200205000-00001

[24] T. D. Jones, T. M. Ulbright, J. N. Eble, L. A. Baldridge and L. Cheng, "OCT4 Staining in Testicular Tumors: A Sensitive and Specific Marker for Seminoma and Embryonal Carcinoma," American Journal of Surgery Pathology, Vol. 28, No. 7, 2004, pp. 935-940. doi:10.1097/00000478-200407000-00014

[25] D. Cao, J. Li, C. C. Guo, R. W. Allan and P. A. Humphrey, "SALL4 is a Novel Diagnostic Marker for Testicular Germ Cell Tumors," American Journal of Surgery Pathology, Vol. 33, No. 7, 2009, pp. 1065-1077. doi:10.1097/PAS.0b013e3181a13eef

[26] I. Gashaw, O. Dushaj, R. Behr, K. Bierman, R. Brehm, H. Rubben, R. Grobholz, K. W. Schmid, M. Bergmann and E. Winterhager, "Novel Germ Cell Markers Characterize Testicular Seminoma and Fetal Testis," Molecular Human Reproduction, Vol. 13, No. 10, 2007, pp. 721-727. doi:10.1093/molehr/gam059

[27] E. C. Jones, S. K. Murray and R. H. Young, "Cysts and Epithelial Proliferations of the Testicular Collecting System," Seminars in Diagnostic Pathology, Vol. 17, No. 4, 2000, pp. 270-293.

[28] C. A. Stratakis, "Clinical Genetics of Multiple Endocrine Neoplasias, Carney Complex and Related Syndromes," Journal of Endocrinological Investigation, Vol. 24, No. 5, 2001, pp. 370-383.

[29] S. S. Kratzer, T. M. Ulbright, A. Talerman, J. R. Srigley, L. M. Roth, G. R. Wahle, M. Moussa, J. K. Stephens, A. Millos and R. H. Young, "Large Cell Calcifying Sertoli Cell Tumor of the Testis: Contrasting Features of Six Malignant and Six Benign Tumors and a Review of the Literature," American Journal of Surgery Pathology, Vol. 21, No. 11, 1997, pp. 1271-1280. doi:10.1097/00000478-199711000-00002

[30] B. Chang, J. G. Borer, P. E. Tan and D. A. Diamond, "Large-Cell Calcifying Sertoli Cell Tumor of the Testis: Case Report and Review of the Literature," Urology, Vol. 52, No. 3, 1998, pp. 520-522. doi:10.1016/S0090-4295(98)00246-5

[31] F. F. Nogales, M. Andujar, A. Zuluaga and J. L. Garcia-Puche, "Malignant Large Cell Calcifying Sertoli Cell Tumor of the Testis," Urology, Vol. 153, No. 6, 1995, pp. 1935-1937. doi:10.1016/S0022-5347(01)67361-0

[32] T. M. Ulbright, M. B. Amin and R. H. Young, "Intratubular Large Cell Hyalinizing Sertoli Cell Neoplasia of the Testis: A Report of 8 Cases of a Distinctive Lesion of the Peutz-Jeghers Syndrome," American Journal of Surgery Pathology, Vol. 31, No. 6, 2007, pp. 827-835. doi:10.1097/PAS.0b013e3180309e33

[33] G. D. Braunstein, “Aromatase and Gynecomastia," En-
docrine-Related Cancers, Vol. 6, No. 2, 1999, pp. 315324. doi: $10.1677 /$ erc. 0.0060315

[34] E. Harris, P. Mahendra, H. H. McGarrigle, D. C. Linch and R. Chatterjee, "Gynaecomastia with Hypergonadotrophic Hypogonadism and Leydig Cell Insufficiency in Recipients of High-Dose Chemotherapy or Chemo-Radiotherapy," Bone Marrow Transplant, Vol. 28, No. 12, 2001, pp. 1141-1144. doi:10.1038/sj.bmt.1703302

[35] H. Barroca, M. J. Gil-da-Costa and C. Mariz, "Testicular Juvenile Granulosa Cell Tumor: A Case Report," Acta Cytologica, Vol. 51, No. 4, 2007, pp. 634-636. doi: $10.1159 / 000325815$

[36] R. Fagin, E. Berbescu, S. Landis, K. Strumpf and U. Patil, "Juvenile Granulosa Cell Tumor of the Testis," Urology, Vol. 62, No. 2, 2003, p. 351. doi:10.1016/S0090-4295(03)00355-8

[37] F. Gun, B. Erginel, I. Klcaslan, S. Anak, O. Ziylan and A. Celik, "A Rare Neonatal Testicular Tumor: Juvenile Granulosa Cell Tumor of Infant Testis: A Report of 3 Cases," Journal of Pediatric Hematology/Oncology, Vol. 32, No. 4, 2010, pp. E158- E159. doi:10.1097/MPH.0b013e3181d69afa

[38] K. H. Hammerich, S. Hille, G. E. Ayala, T. M. Wheeler, R. Engers, R. Ackermann and V. Mueller-Mattheis, "Malignant Advanced Granulosa Cell Tumor Ofthe Adult Testis: case Report and Review of the Literature," Human Pathology, Vol. 39, No. 5, 2008, pp. 701-709. doi:10.1016/i.humpath.2007.09.015

[39] J. A. Hanson and A. B. Ambaye, "Adult Testicular Granulosa Cell Tumor: A Review of the Literature for Clinicopathologic Predictors of Malignancy," Archives of Pathology \& Laboratory Medicine, Vol. 135, No. 1, 2011, pp. 143-146.

[40] I. A. Al-Bozom, S. R. El-Faqih, S. H. Hassan, A. E. El-Tiraifi and R. F. Talic, "Granulosa Cell Tumor of the Adult Type: A Case Report and Review of the Literature of a Very Rare Testicular Tumor" Archives of Pathology \& Laboratory Medicine, Vol. 124, No. 10, 2000, pp. 1525-1528.

[41] J. Arzola, R. L. Hutton, S. M. Baughman and R. V. Mora, "Adult-Type Testicular Granulosa Cell Tumor: Case Report and Review of the Literature," Urology, Vol. 68, No. 5, 2006, pp. E13-E16. doi:10.1016/j.humpath.2007.09.015

[42] P. Ditonno, G. Lucarelli, M. Battaglia, V. Mancini, S. Palazzo, S. Trabucco, C. Bettocchi and F. Paolo Selvaggi, "Testicular Granulosa Cell Tumor of Adult Type: A New Case and a Review of the Literature," Urology Oncology, Vol. 25, No. 4, 2007, pp. 322-325.

doi:10.1016/j.urolonc.2006.08.019

[43] T. Guzzo, M. Gerstein and J. H. Mydlo, "Granulosa Cell Tumor of the Contralateral Testis in a Man with a History of Cryptorchism," Urology, Vol. 72, No. 1, 2004, pp. 85-87. doi:10.1159/000075281

[44] M. Hisano, F. M. Souza, D. M. Malheiros, A. C. Pompeo and A. M. Lucon, "Granulosa Cell Tumor of the Adult Testis: Report of a Case and Review of the Literature," Clinics, Vol. 61, No. 1, 2006, pp. 77-78. doi:10.1590/S1807-59322006000100013 
[45] J. I. Lopez, "Adult-Type Granulosa Cell Tumor of the Testis: Report of a Case," Tumori, Vol. 93, No. 2, 2007, pp. 223-224.

[46] A. Suppiah, M. M. Musa, D. R. Morgan and A. D. North, "Adult Granulosa Cell Tumour of the Testis and Bony Metastasis: A Report of the First Case of Granulosa Cell Tumour of the Testicle Metastasising to Bone," Urology, Vol. 75, No. 1, 2005, pp. 91-93. doi:10.1159/000085936

[47] B. Y. Wang, D. S. Rabinowitz, R. C. Granato Sr. and P. D. Unger, "Gonadal Tumor with Granulosa Cell Tumor Features in an Adult estis," Diagnostic Pathology, Vol. 6, No. 1, 2002, pp. 56-60. doi:10.1053/adpa.2002.30607

[48] J. Cohen and I. Diamond, "Leontiasis Ossea, Slipped Epiphyses, and Granulosa Cell Tumor of Testis with Renal Disease: Report of a Case with Autopsy Findings," AMA Arch Pathology, Vol. 56, No. 5, 1953, pp. 488-500.

[49] J. Matoska, D. Ondrus and A. Talerman, "Malignant Granulosa Cell Tumor of the Testis Associated with Gynecomastia and Long Survival," Cancer, Vol. 69, No. 7, 1992, pp. 1769-1772. doi:10.1002/1097-0142(19920401)69:7<1769::AID-CNC R2820690719>3.0.CO;2-V

[50] F. K. Mostofi, E. A. Theiss and D. J. Ashley, "Tumors of Specialized Gonadal Stroma in Human Male Patients, Androblastoma, Sertoli Cell Tumor, Granulosa-Theca Cell Tumor of the Testis, and Gonadal Stromal Tumor," Cancer, Vol. 12, 1959, pp. 944-957. doi:10.1002/1097-0142(195909/10)12:5<944::AID-CNC R2820120515>3.0.CO;2-T

[51] F. K. Mostofi and V. M. Bresler, "Tumours of the Testis," IARC Scientific Publications, Bhopal, 1976.

[52] L. P. Jimenez-Quintero, J. Y. Ro, A. Zavala-Pompa, M. B. Amin, B. Tetu, N. G. Ordonez and A. G. Ayala, "Granulosa Cell Tumor of the Adult Testis: A Clinicopathologic Study of Seven Cases and a Review of the Literature," Human Pathology, Vol. 24, No. 10, 1993, pp. 1120-1125. doi:10.1016/0046-8177(93)90193-K

[53] S. T. Schumer and S. A. Cannistra, "Granulosa Cell Tumor of the Ovary," Journal of Clinical Oncology, Vol. 21, No. 6, 2003, pp. 1180-1189. doi:10.1200/JCO.2003.10.019

[54] M. P. Laguna, G. Pizzocaro, O. Klepp, F. Algaba, L. Kisben" European Urology, Vol. 40, No. 2, 2001, pp. 102-110. doi:10.1159/000049759

[55] P. Albers, W. Albrecht, F. Algaba, C. Bokemeyer, G. Cohn-Cedermark, A. Horwich, O. Klepp, M. P. Laguna and G. Pizzocaro, "Guidelines on Testicular Cancer" European Urology, Vol. 48, No. 6, 2005, pp. 885-894. doi:10.1016/j.eururo.2005.06.019

[56] S. P. Bowers, N. W. Pearlman, R. C. McIntyre Jr., C. A. Finlayson and S. Huerd, "Cost-Effective Management of Gynecomastia," American Journal of Surgery 1, Vol. 176, No. 6, 1998, pp. 638-641.

[57] I. R. Daniels and G. T. Layer, "Testicular Tumours Presenting as Gynaecomastia," European Journal of Surgery Oncology, Vol. 29, No. 5, 2003, pp. 437-439. doi:10.1016/S0748-7983(03)00004-0

[58] A. A. Ismail and J. H. Barth, "Endocrinology of Gynae- comastia," Annals of Clinical Biochemistry, Vol. 38, 2001, pp. 596-607. doi:10.1258/0004563011900993

[59] E. H. Hernes and K. Harstad Fossa, "Changing Incidence and Delay of Testicular Cancer in Southern Norway (1981-1992)," European Urology, Vol. 30, No. 3, 1996, pp. 349-357.

[60] L. J. Hands and M. J. Greenall, "Gynaecomastia," British Journal of Surgery, Vol. 78, No. 8, 1991, pp. 907-911. doi:10.1002/bjs. 1800780805

[61] A. V. Stepanas, N. A. Samaan, P. N. Schultz and P. Y. Holoye, "Endocrine Studies in Testicular Tumor Patients with and without Gynecomastia: A Report of 45 Cases," Cancer, Vol. 41, No. 1, 1978, pp. 369-376. doi:10.1002/1097-0142(197801)41:1<369::AID-CNCR28 20410150>3.0.CO;2-Y

[62] A. Tseng Jr., S. J. Horning, F. S. Freiha, K. J. Resser, J. F. Hannigan Jr. and F. M. Torti, "Gynecomastia in Testicular Cancer Patients. Prognostic and Therapeutic Implications," Cancer, Vol. 56, No. 10, 1985, pp. 2534-2538. doi:10.1002/1097-0142(19851115)56:10<2534::AID-CN CR2820561036>3.0.CO;2-Q

[63] R. E. Emerson and T. M. Ulbright, "Intratubular Germ Cell Neoplasia of the Testis and Its Associated Cancers: The Use of Novel Biomarkers," Pathology, Vol. 42, No. 4, 2010, pp. 344-355. doi:10.3109/00313021003767355

[64] N. E. Skakkebaek, "Atypical Germ Cells in the Adjacent "Normal" Tissue of Testicular Tumours," Acta Pathology Microbiology Scand A, Vol. 83, No. 1, 1975, pp. 127-130.

[65] N. E. Skakkebaek, "Carcinoma in Situ of the Testis: Frequency and Relationship to Invasive Germ Cell Tumours in Infertile Men," Histopathology, Vol. 2, No. 3, 1978, pp. 157-170. doi:10.1111/j.1365-2559.1978.tb01706.x

[66] C. Winter and P. Albers, "Testicular Germ Cell Tumors: Pathogenesis, Diagnosis and Treatment," Nature Reviews Endocrinology, Vol. 7, No. 1, 2011, pp. 43-53. doi:10.1038/nrendo.2010.196

[67] S. Gori, S. Porrozzi, F. Roila, G. Gatta, U. De Giorgi and M. Marangolo, "Germ Cell Tumours of the Testis," Critical Reviews in Oncology/Hematology, Vol. 53, No. 2, 2005, pp. 141-164. doi:10.1016/j.critrevonc.2004.05.006

[68] N. Javadpour, K. R. McIntire and T. A. Waldmann, "Human Chorionic Gonadotropin (HCG) and Alpha-Fetoprotein (AFP) in Sera and Tumor Cells of Patients with Testicular Seminoma: A Prospective Study," Cancer, Vol. 42, No. 6, 1978, pp. 2768-2772. doi:10.1002/1097-0142(197812)42:6<2768::AID-CNCR2 820420636>3.0.CO;2-Z

[69] C. Duparc, G. Boissiere-Veverka, H. Lefebvre, A. Laquerriere, P. Vuillermet, A. Landreat, R. Ivell, N. DeRoux and J. M. Kuhn, "An Oestrogen-Producing Seminoma Responsible for Gynaecomastia," Hormone and Metabolic Research, Vol. 35, No. 5, 2003, pp. 324-329. doi: $10.1055 / \mathrm{s}-2003-41310$

[70] T. Yamashiro, Y. Iraha, H. Kamiya, T. Nakayama, S. Unten and S. Murayama, "Testicular Seminoma Presenting with Mediastinal Lymphadenopathy and Gynecomastia," Radiation Medicine, Vol. 25, No. 6, 2007, pp. 303305. doi:10.1007/s11604-007-0137-3 
[71] D. Kammerer-Doak, K. Baurick, W. Black, D. M. Barbo and H. O. Smith, "Endodermal Sinus Tumor and Embryonal Carcinoma of the Ovary in a 53-year-old Woman," Gynecology Oncology, Vol. 63, No. 1, 1996, pp. 133-137. doi:10.1006/gyno.1996.0292

[72] T. Motoyama, H. Watanabe, T. Yamamoto and M. Sekiguchi, "Production of Beta-Human Chorionic Gonadotropin by Germ Cell Tumors in vivo and in vitro," Acta Pathologica Japonica, Vol. 38, No. 5, 1988, pp. 577-590.
[73] M. Harris, S. Rizvi, J. Hindmarsh and R. Bryan, "Testicular Tumour Presenting as Gynaecomastia," British Medical Journal, Vol. 332, No. 7545, 2006, p. 837. doi:10.1136/bmj.332.7545.837

[74] W. S. Hendry, W. H. Garvie, A. K. Ah-See and A. P. Bayliss, "Ultrasonic Detection of Occult Testicular Neoplasms in Patients with Gynaecomastia," British Journal of Radiology, Vol. 57, No. 679, 1984, pp. 571-572. doi:10.1259/0007-1285-57-679-571 